\title{
Detection of cancer stem cells by immunohistochemistry of canine mammary neoplasias
}

\author{
Geórgia Modé Magalhães ${ }^{*}$, Erika M Terra², Rosemeri O Vasconcelos ${ }^{1}$, Mayara C Rosolem, Márcio B Bandarra', \\ Pâmela RR Moreira ${ }^{1}$, Antonio C Alessi ${ }^{1}$
}

From São Paulo Advanced School of Comparative Oncology

Águas de São Pedro, Brazil. 30 September - 6 October 2012

\section{Background}

Canine mammary neoplasias are very common and, in Brazil, 70\% are considered malignant. Cancer stem cells (CSCs) are able to self-renew and have abilities to form metastases. In canine mammary tumors these CSCs were isolated by flow cytometry by means of the surface markers CD44+/CD24-. The aims of this study was detect these CSCs by immunohistochemical reactions and correlate them with degrees of canine mammary neoplasias.

\section{Patients and methods}

A total of 130 breast cancer samples were selected from the Unesp - Department of Pathology and classified according to [1]. These samples were composed of adenomas; metastasis, solid carcinoma grades II and III; tubular, papillar and mixed tumor carcinoma grades I, II and III. Immunohistochemical was performed with antibodies CD44 and CD24.

\section{Results}

A regression line by Pearson correlation test was performed. The value which CD44 is positive and CD24 becomes zero is $46.75 \%$. From 130 samples, 40 showed the phenotype CD44+/CD24-Thirty seven was metastasis, grades II and III. The immunostainings for CD44 and CD24 antibodies were respectively $62.2 \%$ and $0 \%$. In the literature, grade III are more correlated with CD44 than CD24. In studies by flow cytometry authors found percentages of CSCs similar to those found in this work.

\section{Conclusion}

The immunohistochemistry showed to be a reliable technique for detection CSCs in canine mammary neoplasias and correlates with grades II and III (poor prognosis).

\section{Financial support \\ CNPq.}

\section{Author details}

'Department of Veterinary Pathology, UNESP, Jaboticabal, SP, Brazil. ${ }^{2}$ Department of Veterinary Clinics and Surgery, UNESP, Jaboticabal, SP, Brazil.

Published: 4 April 2013

\section{Reference}

1. Cassali GD, Lavalle GE, De Nardi AB, Ferreira E, Bertagnolli AC, EstrelaLima A, Alessi AC, Daleck CR, Salgado BS, Fernandes CG, Sobral RA, Amorim RL, Gamba CO, Damasceno KA, Auler PA, Magalhães GM, Silva JO, Raposo GB, Ferreira AMR, Oliveira LO, Malm C, Zuccari DAPC, Tanaka NM, Ribeiro LR, Campos LC, Souza CM, Leite JS, Soares LMC, Cavalcanti MF, Fonteles ZGC, Schuch ID, Paniago J, Oliveira TS, Terra EM, Castanheira TLL, Felix AOC, Carvalho GD, Guim TN, Guim TN, Garrido E, Fernandes SC, Maia FCL, Dagli MLZ, Rocha NS, Fukumasu H, Grandi F, Machado JP, Silva SMMS, Bezerril JE, Frehse MS, Almeida ECP, Campos CB: Consensus for the diagnosis, prognosis and treatment of canine mammary tumors. Braz J Vet Pathol 2011, 4(2):153-180.

\section{doi:10.1186/1753-6561-7-S2-P28}

Cite this article as: Magalhães et al:. Detection of cancer stem cells by immunohistochemistry of canine mammary neoplasias. BMC Proceedings 2013 7(Suppl 2):P28.

* Correspondence: georgiamode@hotmail.com

'Department of Veterinary Pathology, UNESP, Jaboticabal, SP, Brazil

Full list of author information is available at the end of the article 